
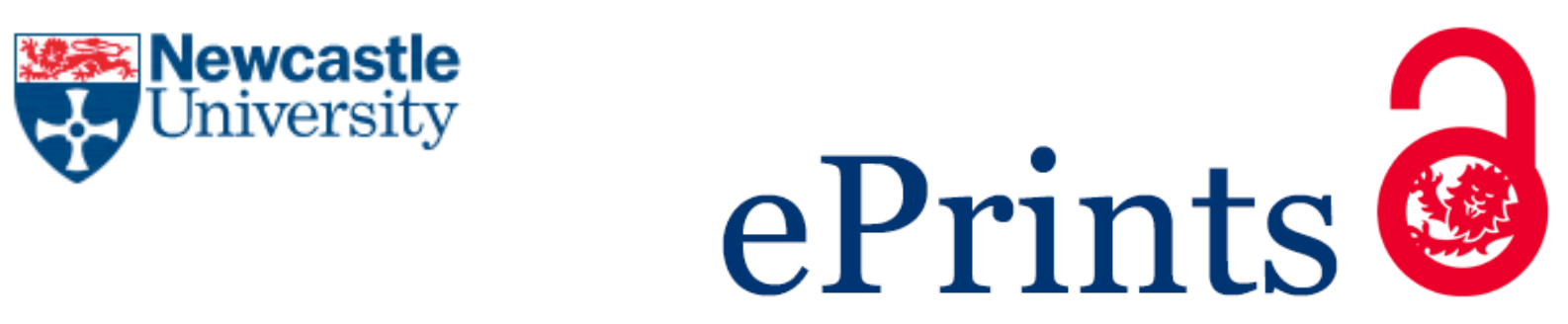

\title{
Connolly Ruth.
}

Hester Pulter's Childbirth Poetics.

Women's Writing 2016

DOI: http://dx.doi.org/10.1080/09699082.2016.1261639

\section{Copyright:}

This is an Accepted Manuscript of an article published by Taylor \& Francis in Women's Writing on 15 December 2016, available online: http://www.tandfonline.com/10.1080/09699082.2016.1261639

DOI link to article:

http://dx.doi.org/10.1080/09699082.2016.1261639

Date deposited:

$16 / 12 / 2016$

Embargo release date:

15 June 2018

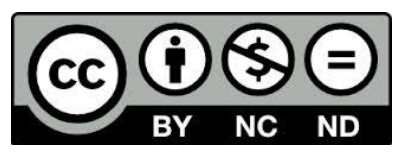

This work is licensed under a

Creative Commons Attribution-NonCommercial-NoDerivatives 4.0 International licence 
Title: Hester Pulter's Childbirth Poetics

Abstract: Hester Pulter's poem from the lying-in chamber exemplifies of a wider practice in her poetic of foregrounding the sexed female body in her work. This poem's literalisation of the metaphor of the poet-in-childbirth begins Pulter's re-examination of her culture's positioning of her body and her writing from the point-of-view of experiential and experimental knowledge. The configurations of bodies - heavenly and human - offered by the early modern habit of thinking by correspondence with one another offer Pulter a route that positioning and to construct a counterperspective from which to survey it.

Keywords: poetics, childbirth, Galen, Galileo, body, maternity, correspondence

Author: Ruth Connolly

Affiliation: Newcastle University, UK

Postal Address: SELS, Percy Building, Newcastle University, Newcastle upon Tyne, NE1 7RU, UK

Email: ruth.connolly@,ncl.ac.uk

Telephone: 01912088133 
What does it matter if the 'pregnant poet' actually is pregnant?' ${ }^{1}$ Hester Pulter's poem from the birthing chamber, 'when I Lay Inn', literalises the trope rife in early modern writing of creativity as maternity. Deployed by writers in all genres and modes and across the spectrum from hack writer to court poet, the example most widely known to modern readers is probably Philip Sidney's witty description of his poetic persona as 'great with Childe to speake, and helplesse in my throwes'. ${ }^{2}$ More broadly, the poem exemplifies the ways in which the sexed female body underpins her poetic and informs the principal motifs of her poetry: the endless revolutions of matter and spirit through stages of birth and death, disintegration and regeneration. Her poem does not straightforwardly affirm a gynocentric universe but establishes the ambivalent implications for the woman writer of the maternal body's centrality to creative experience in early modern lyric. It relies on another practice central to Pulter's work, which is thinking by analogy or correspondence. In this poem, Pulter exploits the reciprocity this practice entailed to re-examine representations of the female body in light of Galileo's revisions of the model of the cosmos. In doing so she reworks the trope of the 'pregnant poet' in a way which responds to the materialities of the female body as it is understood and experienced in the early modern period.

Analogical thinking is a well-established pattern of thought in the mid-seventeenth century. As Ann Baynes Coiro elegantly summarises: ' $[\mathrm{P}]$ olitical and social relationships were understood by organic

\footnotetext{
${ }^{1}$ Versions of this paper have been presented at conferences and visiting speakers' series at University College Cork, Durham University and Cambridge University. I am grateful to those audiences and to the journal's anonymous readers for their comments, questions and generously shared references.

${ }^{2}$ Sir P.S. His Astrophel and Stella (London, 1591), Sig. A2r. For numerous early modern examples of this motif from Shakespeare and others, see Elizabeth Sacks, Shakespeare's Images of Pregnancy (London: Macmillan, 1980). Terry Castle gives an overview of the metaphor's classical origins and eighteenth-century development in "'Lab'ring bards': Birth Topoi and English Poetics," Journal of English and Germanic Philology 78 (1979): 193-208. See also Anna-Julia Zwierlen, "Male Pregnancies, Virgin Births, Monsters of the Mind: Early Modern Melancholia and (Cross-)Gendered Constructions of Creativity" in The Literature of Melancholia: Early Modern to Postmodern, ed. Martin Middeke and Christina Wald (Basingstoke: Palgrave Macmillan, 2011), 35-49.
} 
correspondence. The state was conceived of as a human body, for example, the king, the body's head. Or the state was understood as a family, the king its father and husband. Such biological, physical analogues were enormously powerful, embracing and reciprocal. ${ }^{3}$ But whilst these analogues were regularly used to insist that existing hierarchies of power were as natural and absolute as the head's command of the body, they were also flexible enough to deploy as illustrations of the interdependence and interpenetration of all parts of the body politic. The Speaker of the House of Commons, Sir Edward Phelips, reminded the newly incumbent James I that the 'Head', though unquestionably 'the supreme and commanding part' cannot 'stand secure without his Subjects', in his reply to James' accession speech in which the King had announced that 'the head is ordained for the body and not the body for the Head. ${ }^{4}$ This way of reading the world went far beyond the political. In its widest application, Mazzeo notes, the 'universe is a vast net of correspondences that unites the whole multiplicity of being. ${ }^{5}$ The exploration of the world through analogical correspondence plays a definitive role in Pulter's poetry. Sarah Hutton and Jayne Archer have already established the ways in which Pulter treats the cosmological, spiritual, political and domestic in terms which are reciprocally illuminating. Hutton has described how Pulter uses her cutting-edge knowledge of the findings of Galilean science to make 'unconventional adaptations of conventional spiritual motifs. ${ }^{6}$ Jayne Archer's brilliant account of Pulter's use of alchemical symbolism in her poetry argues that Pulter finds a set of principles in alchemy which enable her to read the physical processes of alchemical experiment as corresponding symbolically to personal spiritual processes and potentially to political processes as well. ${ }^{7}$ The centrality of correspondence to her poetic and politics is vividly illustrated by Rachel Dunn's recent work on Pulter's post-regicide political emblems. Dunn argues that these poems deliberately break the principle of analogy to which the genre is committed, a practice intended to register how incomparable the situation in which England finds itself is 'as she struggles to accommodate the genre to a contemporary reality

\footnotetext{
${ }^{3}$ Ann Baynes Coiro, "'A ball of strife': Caroline Poetry and Royal Marriage" in The Royal Image: Representations of Charles I ed. Thomas Corns, (Cambridge: Cambridge UP, 1999), 28.

${ }^{4}$ Quoted in Peter C. Hermann, 'Macbeth: Absolutism, the ancient constitution, and the aporia of politics' in Law and Shakespeare, ed. Constance Jordan and Karen Cunningham (Basingstoke: Macmillan, 2007), 208-232 (211-12). ${ }^{5}$ Joseph Anthony Mazzeo, "Metaphysical Poetry and the Poetic of Correspondence," Journal of the History of Ideas 14.2 (1953): 230. See also William J. Mills, "Metaphorical Vision: Changes in Western Attitudes to the Environment," Annals of the Association of American Geographers 72.2. (1982): 237-253.

${ }^{6}$ Sarah Hutton, "Hester Pulter (c. 1596-1678): A Woman Poet and the New Astronomy", Études Épistémè 14 (2008): 79.

7 Jayne Archer, "A "Perfect Circle"? Alchemy in the Poetry of Hester Pulter" Literature Compass: The Seventeenth Century 2.1 (2005): 1-14. DOI: 10.1111/j.1741-4113.2005.00160.x
} 
that (in her understanding) completely lacks analogical parallel; reality calls into question the basic principles on which the form depends: comparison, likeness, analogy. ${ }^{98}$

This practice is evident in a different form in her lyric poetry. Here Pulter uses Ovidian models to create a gynocentric model of correspondence. The two forces that Pulter's speakers perceive as constructing the world and human society, Light and Justice, are persistently represented as the mother and daughter, Aurora and Astrea, and the two forces she sees as anticipating its destruction are also mother and daughter, Night and Error. The succession of Aurora by Night and vice-versa frequently serves as a means of figuring the emotional geography of her poems, mapping alternating states of ecstatic liberation and acute depression and grief onto larger cosmological and mythological patterns of darkness and light, transformation and revolution. The threshold moments in these transitions are represented as spaces of birth. Her poem 'Universall dissolution made when I was with child of the $15^{\text {th }}$ child being as everyone thought in a consumption 1648,' a meditation on the eventual fall of all earthly things, represents the dawn goddess as a mother triumphant after labour:

Nay mark Aurora in her youthfull pride

Her purple Curtains newly drawn aside

As when her blessed Infant shee brought forth

The faire Astrea of unparrel'd worth

Bright is the one but brighter is the other

The Daughter infinitely excels the Mother (11. 106-11) ${ }^{9}$

In this praise of the birth of daughters lies one of Pulter's favourite images: Dawn or Light giving birth to Justice, a trope which is used in her work to blend the space of childbirth with matrilineal virtue, literary creativity and political authority. This feminisation of Genesis ('let there be light') reenacts the remaking of the world with each dawn and the departure of Night is read as the defeat of

\footnotetext{
${ }^{8}$ Rachel Dunn, "Breaking a Tradition: Hester Pulter and the English Emblem Book," The Seventeenth Century 30.1 (2015): 62.

${ }^{9}$ Hester Pulter, "Poems wrighten by the Right Honerable H.P.", Leeds UL, Brotherton MS Lt q 32, fol.12r. I have regularised $u / v$ and $i / j$ substitutions but otherwise retained the original spelling and orthography. For a modern spelling edition of Pulter's complete works, see Alice Eardley, ed. Poems, Emblems and The Unfortunate Florinda, by Lady Hester Pulter (Toronto: Iter Inc, and the Centre for Reformation and Renaissance studies, 2014).
} 
one feminine force by another. The survival of Justice will then become a matter of maternal nurture. In an address to 'Astrea', which takes on a pointedly political colouring in the context of Pulter's avowed royalism, the speaker pleads for her return:

Leave not (oh leave not) this our Orb of Earth

If Fraud usurps that thou canst find noe rest

Then take thy Lodging up in my poor breast

There thou shalt Monarchise and rule alone

None dareing to displace thee from thy throne (1l. 6-10) ${ }^{10}$

Women's bodies are the last and first site of monarchical government, a government sustained by that body's integrity and renewed through its reproductive potential. Cockeram offers 'domineere' or 'imperate' as synonyms of monarchies and the verb is commonly used to refer to a power which demands or requires submission from its subjects. ${ }^{11}$ Its usages range from a poetic account of Spain's military interventions in the Low Countries in the late sixteenth century to descriptions of the reigns both of Death and of Jesus. ${ }^{12}$ It served as a synonym for comprehensive power: Noah Biggs in 1651 uses it as an alternative to 'monopolize'; James Howell in 1644 described the collapse of French liberties as consequent on the loss of the regular sitting of Parliament enabling the French King to 'monarchise more absolutely'. ${ }^{13}$ In all these cases, the submission of the subject to the monarchising power presumes an inevitable and potentially damaging loss of her agency or liberty, often within the context of a compulsion to obey that is difficult or impossible to resist. In the context of Pulter's poem, this ambivalence centres more on the inadequacy of her speaker's 'poor breast' to house this figure. But she willingly embraces Astrea's rule and the speaker's unity with this figure will hence be indissoluble: 'none daring to displace thee from thy throne/Till everlasting Glory, Joy, and Love/Shall us invite to live with them above.' (1l. 10-12)

\footnotetext{
10 "To Astrea", fol. 41v.

${ }^{11}$ Henry Cockeram, The English Dictionarie (London, 1623), Sig. C7r.

${ }^{12}$ William Crosse, Belgia's Troubles and Triumphs (London, 1625) sig. C4v; William Drummond, Poems (Edinburgh, 1616), Sig. H4v; Thomas Heywood, The Hierarchie of the Blessed Angels (London, 1635), sig. C1r. ${ }^{13}$ Noah Biggs, Mataeotechnia medicinae praxeos, The vanity of the craft of physic (London, 1651), Sig. D3r; James Howell, Two discourses lately review'd and enrich'd by the author (London, 1644), Sig. B1v.
} 
The claim (and its attendant ambivalences) is made and maintained in the poem through the gendered correspondence between the body of justice and the body of the speaker and through the mother-child relationship that calls both into being. This practice of literalising the metaphorical is one of Pulter's most frequently used poetic strategies and one she utilises in order to assert(to repeat Coiro's formulation) a powerful and reciprocal link between women's intellectual creativity and authority and their experience of their bodies. Pulter uses a maternal poetic to place her speakers as both participants in and knowledgeable observers of a world read as a series of analogous cycles. By using maternal experience as the entrance point for unlocking the significance of these cycles and to articulate her own subjectivity, what Pulter gropes towards is a space that articulates a feminine literary agency, a power located in the sexed female body as the literal ground and figurative space of creation. Her work reveals a telling and culturally rare moment in early modern poetics when the female body is read not as a site of eroticism or pathology, but as a normative space of creation. That creativity is also understood in terms of bodily surrender, and the use of a metaphor of maternity to denote that surrender is not accidental. As Laura Gowing points out, [i] nstead of the autonomy or control that modern women might seek over (for example) pregnancy and childbirth, early modern women sought to resign themselves: to the authority of family and husbands, and the will of God. ${ }^{14}$ Pulter's experience of fifteen live births gave her many opportunities to practice such resignations.

However, as Sarah Ross remarks, it is 'not possible in Pulter's case to erase the ontological connection between her sexed body and the act of politicized speech. ${ }^{15}$ Pulter's refusal of such an erasure - her deliberate appropriation of that body as a site of authority in the context of a barrage of political, cultural and medical discourses that insisted on the female body's instability and inferiority — warrants close examination. Gowing has found historical evidence of women talking about their bodies and particularly about 'sex, pregnancy or childbirth' only in 'exceptional, usually negative circumstances. ${ }^{16}$ This rare evidence of how an early modern woman regarded her body also informs and can be informed by the movement in feminist thought that explores how to talk

\footnotetext{
${ }^{14}$ Laura Gowing, Common Bodies: Women, Touch and Power in Seventeenth-Century England (New Haven: Yale, 2003), p. 11.

${ }^{15}$ Sarah C. E. Ross, Women, Poetry and Politics in Seventeenth-Century Britain (Oxford: Oxford UP, 2015), 155. Kate Chedgzoy earlier identified the centrality of the sexed body in Pulter's work. See her Women's Writing in the British Atlantic World: Memory, Place and History (Cambridge: Cambridge UP, 2007), 144-153.

${ }^{16}$ Gowing, p. 10.
} 
'about bodies and the materiality they inhabit. ${ }^{17}$ This critical return to the matter of the body and the attempt to recover and find ways to talk about embodied experience in a manner which neither erases nor essentialises matter is part of a wider bid by feminist thought to re-examine issues of subjectivity, autonomy and agency for the female subject Karen Barad sees the critical silence on the significance of the material body, and the female body in particular, as problematic because it implicitly accepts the binaries of nature/culture, female/male, passive/active and consequently the construction of 'nature' as passive. A better approach, she argues, is to disrupt this binary by exploring how matter might be understood to exercise agency. ${ }^{18}$ One means of doing so is to ask how the experience of a particular body might inform a critical understanding of the world. Pulter's work with its particular emphasis on the sexed body of the speaker, helps us not only to answer this question but does so in a manner which impels the historicisation of that question. How does the experience of a sexed female body, as that body is understood in the mid-seventeenth century, shape this poet's critical understanding of herself and her writing?

The early modern body is based on a humoural model and Michael Shoenfeldt has argued that model's biologically inaccurate but intuitively persuasive accounts of the body represent 'not so much the actual workings of the body as the experience of the body. ${ }^{, 19}$ Gail Kerns Paster sees within the tight links which Galenic medicine forges between physiology and psychology an idea of the body and mind which is open to the more-than-human world: 'humoural subjectivity becomes recognisable as a form of consciousness inhabited by, even as it inhabits, a universe composed of analogous elements. ${ }^{, 20}$ This then is a model of subjectivity which understands the self as less separated from and less opposed to the world outside, a model whose boundaries are porous, and

\footnotetext{
${ }^{17}$ Myra J. Hird, "Feminist Matters: New Materialist Considerations of Sexual Difference" Feminist Theory 5.2 (2004): 227. See also Stacy Alaimo and Susan Hekman, "Emerging Models of Materiality in Feminist Theory," in Material Feminisms ed. by Stacy Alaimo and Susan Hekman (Bloomington and Indianapolis: Indiana University Press, 2008), 1-19 and Diana Coole and Samantha Frost, 'Introducing the New Materialisms', in New Materialisms: Ontology, Agency and Politics, ed. by Diana Coole and Samantha Frost (Durham, NC: Duke University Press, 2010), 1-43.

${ }^{18}$ Karen Barad, "Posthumanist Performativity: Towards an Understanding of How Matter Comes to Matter," in Material Feminisms ed. by Alaimo and Hekman, 120-154 and Susan Hekman, "Constructing the Ballast: An Ontology for Feminism," in Material Feminisms ed. by Alaimo and Hekman, 103.

${ }^{19}$ Michael C. Schoenfeldt, Bodies and Selves in Early Modern England: Physiology and Inwardness in Spenser, Shakespeare, Herbert and Milton (Cambridge: Cambridge UP, 1999), 3.

${ }^{20}$ Gail Kern Paster, "Melancholy Cats, Lugged Bears and Early Modern Cosmology: Reading Shakespeare's Psychological Materialism across the species barrier" in Reading the Early Modern Passions: Essays in the Cultural History of Emotion, ed. by Gail Kern Paster, Katherine Rowe and Mary Floyd-Wilson (Philadelphia: $\mathrm{U}$ of Pennsylvania Press, 2004), 117.
} 
open to alteration by that world. Pulter characterises her psychological disposition toward melancholy as a consequence of multiple inter-related factors including a predominance of the relevant humour — black bile — in her physiological makeup, the astrological timing of her birth, bitter personal experiences of childloss, and a series of associated environmental factors, which include the intensification of melancholy in periods of actual darkness. In another poem addressed to Aurora, the speaker reflects that her suffering is most acute in times of actual as well as figurative darkness. ${ }^{21}$ This is represented as an attack by Night's daughters, the snake-haired Eumenides, who in Greek mythology are figures of vengeance (and in some traditions, justice) who hunt down their victims under their mother's protection. In Pulter's work they are figures who are consistently attracted by pain and fear.

\section{horrid Night}

Whose furious issue straight theire curles unrowles

To lash and torture poore afflicted soules

Oft times they craule into my trembling brest

That I choose strangling rather then such rest

Sometimes they take advantage of my feare

Then strange Cemerian sights seeme to apeare

Unto my troubled fancie then againe

They take Advantage from my Griefe or paine

Presenting death in his most horrid'st shape,

Then of my reason straight they make a rape (11. 32-34; 39-46)

The poem parallels the address to 'Astrea' but this invasion is unwanted, figured in terms of physical, sexual assault on the body, the pain of which then prompts her own poetic maternity. Her

${ }^{21}$ Pulter, "To Aurora," fol. 8r. 
imagination produces monstrous and unnatural chimeras - creatures part lion, part serpent, part goat. Pulter's choice of 'rape' here to describe the Eumenides' actions is striking. Peter C. Hermann shows that Pulter's depiction of rape in her unfinished romance 'The Unfortunate Florinda' adhered to the minority Augustinian view that the 'defilement' of the body of the rape victim could not reach the victim's mind or soul and therefore a victim of rape should consider her chastity undefiled. ${ }^{22}$ This may be crucial to Pulter's willingness to use the term in her poetry. The line quoted utilises a range of meanings of rape, including the seizure of property by force, of sexual assault involving penetration of the body, and, invokes, in Garthine Walker's phrase, the 'annihilation of agency' experienced by a rape victim. ${ }^{23}$ A meaning explored by Amy Greenstadt may be of particular relevance here. She observes how the words 'rapt' and 'ravishing' were 'by the later Middle Ages were used to describe a psychological state in which the individual was transported by an emotional experience. ${ }^{24}$ Such states explained male 'ravishment' by women's beauty but this power was also attributed to works of verbal art. '[A] esthetic beauty and male sexual violence were therefore conceived as forced that invaded the body of another individual through superseding or contradicting his or her will. ${ }^{25}$ Pulter's speaker is ravished by the 'furious issue' of Night through breaches made by 'Griefe or paine', an aesthetic and affective horror that anticipates the paralysing vision of death's victims. The daughters of Night are the nightmares she experiences of lost 'friends' who are, the context of this portrayal suggests, her lost children. The pain of grief is symbolised not by a transport from the body but a terrifying immurement within it.

In that context, the term 'rape' emphasises that this is a physical experience and whereas the poetic description is metaphorical - the psychological pain of grief represented as an act of physical violation and disruption of the body's organs by allegorical figures — it gestures to a physical analogue. In doing so, another shaping influence on Pulter's poetic emerges. In Galenic physiology, both noctural darkness and psychological pain increases the quantities of black bile in the physical body. In turn the predominance of the humour makes the body more open to its corresponding

\footnotetext{
${ }^{22}$ Peter C. Hermann, 'Lady Hester Pulter's The Unfortunate Florinda: Race, Religion, and the Politics of Rape,' Renaissance Quarterly 63.4 (2010), 1208-1246 (1233). Amy Greenstadt provides an important critical reading of the Augustinian position in her" "Rapt from Himself": Rape and the Poetics of Corporeality in Sidney's Old Arcadia' in Representing Rape in Medieval and Early Modern Literature, ed. by Elizabeth Robertson and Christine M. Rose (NY: Palgrave, 2001),

${ }^{23}$ Garthine Walker, 'Rereading Rape and Sexual Violence in Early Modern England', Gender and History 10.1 (1998): 1-25 (19).

${ }^{24}$ Greenstadt, 311.

${ }^{25}$ Greenstadt, 312.
} 
analogues in the outside world. As a result, as Schoenfeldt perceptively notes, Galenic discourse 'gave poets a language of inner emotion whose vehicles were also tenors, whose language of desire was composed of the very stuff of being. ${ }^{26}$ His argument articulates very precisely the interconnections of body, mind, and environment found in 'To Aurora.'

This complex discourse of interiority is highly gendered. Shoenfeldt says he found it impossible to find a woman writer who used Galenic physiology to narrate interiority in the manner of the male poets he discusses and suggests the pejorative account of women's physiology proposed by Galenic medicine is the likely cause. ${ }^{27}$ Galenism categorised women's bodies as cold, moist and therefore suitable for germination, but consequently lacking in wit and intellect, qualities that came more naturally to the possessors of hot, dry bodies. As Katharine Eisaman Maus memorably puts it: 'What makes women fertile — what makes them women — also makes them stupid. ${ }^{28}$ However Pulter proves highly selective in her use of Galenic models. Alice Eardley has described how Pulter's affinity with the planet Saturn, which she saw as responsible for her melancholic disposition, enabled her to appropriate the association between masculine melancholy and intellectual greatness for her own poetic persona, whilst apparently dismissing or ignoring the parallel description of women's melancholy as debilitating and inarticulate. ${ }^{29}$ And as we will see, in 'when I Lay Inn' she recasts the stuff of women's being through re-readings of the more-than-human worlds with which that being corresponded. ${ }^{30}$ Placing the speaker in a threshold state between her son's birth and her own feared death, the poem's narrative connects the female body with a Galilean model of planetary motion and a Neoplatonic interpretation of the soul's return to heaven.

The full title of 'When I Lay Inn' immediately flags a correspondence between maternal physiology — indeed maternal experience — and poetic creativity. Its evocative and lengthy title is 'This was written 1648, when I Lay Inn, with my son John beeing my 15 Child, I beeing soe weak that in Ten

\footnotetext{
${ }^{26}$ Schoenfeldt, 8.

${ }^{27}$ Schoenfeldt, 35-37. More generally, see Gail Kern Paster, “The Unbearable Coldness of Women's Being: Women's Imperfection and the Humoral Economy", English Literary Renaissance 28.3 (1998): 416-440.

${ }^{28}$ Katharine Eisaman Maus, "A Womb of His Own: Male Renaissance Poets in the Female Body" in Sexuality and Gender in Early Modern Europe: Institutions, Texts, Images, ed. by James Grantham Turner (Cambridge: Cambridge UP, 1993), 268.

${ }^{29}$ See Alice Eardley, "'Saturn (whose aspects soe sads my soule)': Lady Hester Pulter's Feminine Melancholic Genius," in New Ways of Looking at Old Texts, ed. by Michael Denbo (Tempe, Arizona: RETS, 2008$), 242$.

30 See Gail Kern Paster, Katherine Rowe and Mary Floyd-Wilson, "Reading the Early Modern Passions", in Reading the Early Modern Passions: Essays in the Cultural History of Emotion, ed. by Paster, Rowe and Floyd-Wilson (Philadelphia: U of Pennsylvania Press, 2004), 1-20.
} 
dayes and Nights I never moved my Head one jot from my Pillow out of which great weaknes, my gracious God restored mee; that I still Live to magnify his Mercie $1655{ }^{31}$ The title is really a retrospective note on the circumstances of the poem's composition. The birth took place in 1648, the title or note or perhaps coda was added in 1655, and the transcription into the folio, judging by the initial scribal slip of writing 1665 for 1655 (an error then corrected in Pulter's hand), took place in that year. The precision with dates and numbers in the note reveals the considerable degree of care taken retrospectively to locate this event in space, time and memory. The note positions the speaker's body at the conclusion of a reproductive cycle, as physically immobile and as having just been delivered — the term 'lying-in' refers specifically to the first month after childbirth — although as we will see the end of the poem seems to suggest the speaker is still in labour. ${ }^{32}$ The body from which the voice emerges is represented as weakened, ill, and yet somehow triumphantly productive — the title carefully specifies a fifteenth child. The title evokes but avoids the ars moriendi tradition, where a physically weak and potentially or actually dying body liberates and legitimates speech. As Diane Purkiss has argued, that tradition is utilised in seventeenth-century radical women's writing as a means of presenting women's speech freed from the clogging and distorting interventions of feminine physiology, placing the spirit 'in heaven or with God, their bodies on earth., ${ }^{33}$ Pulter's poem instead intervenes in and literalises the much more prevalent literary trope in early modern writing of the poet-in-childbirth. In Maus' sensitive and nuanced exploration of the 'poet-inchildbirth' as it is exercised by a number of male writers including Sydney, Jonson and Milton, she concludes that the trope is situated right at the centre of Renaissance uncertainty about the precise relationship between the mind and body. ${ }^{34}$ The seduction, she observes, of drawing an analogy between the creative (male) mind and the fecund (female) body is that it invites and denies both a materialist monist model that makes body and mind the same substance and a hierarchic dualism which appropriates the mysterious inwardness of the womb as a vehicle for an inviolate 'male poetic subjectivity. ${ }^{35}$

\footnotetext{
${ }^{31}$ Pulter, fols. 67r-68v.

${ }^{32}$ Adrian Wilson, Ritual and Conflict: The Social Relations of Childbirth in Early Modern England (Farnham, Surrey: Ashgate, 2013), 170.

${ }^{33}$ See Diane Purkiss, "Producing the Voice, Consuming the Body: Women Prophets of the Seventeenth Century", in Women, Writing, History, 1640-1740 eds. Isobel Grundy and Susan Wiseman (London: Batsford, 1992), 143.

${ }^{34}$ Maus, 276.

${ }^{35}$ Maus, 268.
} 
Women writers faced a different problem appropriating this trope. Whilst women's reproductive organs were described in Galenic medicine as structurally homologous to men's, their bodies contained higher levels of colder fluids, many of which coalesced around the womb, itself a cold organ and 'the transit area and vessel for vast quantities of fluid. ${ }^{36}$ Since creativity was centred on the physiological prevalence of heat and dryness, the 'affinity between childbirth and thinking or speaking' that Maus notes in rhetorical treatises is not culturally extended to those who actually possessed a womb. ${ }^{37}$ Printed medical commentary of the early seventeenth century pathologised the womb to a greater degree than earlier accounts. ${ }^{38}$ In especially pejorative accounts, such as Edward Jorden's treatise $A$ briefe discourse of a disease called the suffocation of the mother (1603), the centrality of the womb in the woman's body and its extensive material connections (via veins, arteries and nerves) to the other principal organs - heart, liver, brain and stomach — gave it the power to affect any part of the body with its own illnesses. ${ }^{39}$ The suffocation of the mother, a disease tied expressly to the womb, made a woman's mind more vulnerable to literal incoherence and to loss of speech than its symbolic nurture or deliverance.

Respiration hath annexed vnto it voyce, and speach, this is diminished or abolished in Suffocation or choaking, from whence this disease which we intreat of taketh his name, as from the most common Symptom which appeareth in it. In difficulty of breathing. In priuation of voyce and speech. ${ }^{40}$

The mother affected reason, memory and imagination. ${ }^{41}$ The sufferer loses the ability to distinguish between fantasy and reality: 'The Internall sence is depraued when a man doth imagine, iudge, or remember thinges that are not as if they were, or things that are, otherwise then they are indeed. ${ }^{42}$

\footnotetext{
${ }^{36}$ Robert Martensen, "The Transformation of Eve: Women's Bodies, Medicine and Culture in Early Modern England" in Sexual Knowledge, Sexual Science: The History of Attitudes to Sexuality ed. Roy Porter and Mikuláš Teich (Cambridge: Cambridge UP, 1994), 107-33 (108). See also Paster, "Unbearable Coldness".

${ }^{37}$ Maus, 276. Helkiah Crooke, Microcosmographia: a description of the body of man (London, 1615), 272-77 rehearses the contemporary debate as to whether women's bodies are hotter or colder than men's. Crooke also dismisses the idea of a structural homology between men and women's bodies.

${ }^{38}$ See Mary Fissell, Vernacular Bodies: The Politics of Reproduction in Early Modern England (Oxford: Oxford UP, 2004) 59-60.

${ }^{39}$ Edward Jorden, A briefe discourse of a disease called the suffocation of the mother (London, 1603) Sig. C2r. See Fissell, Vernacular Bodies, 59. Jorden's claim is reiterated in Helkiah's Crook's treatise on anatomy, Microcosmographia (1615) which endorsed the view (originally derived from Hippocrates) that 'the wombs of women are the causes of all disease,' (252).

${ }^{40}$ Jorden, Sig. E3v. Emphasis in original.

${ }^{41}$ Jorden, Sig. D4v

${ }^{42}$ Jorden, Sig. E1r.
} 
The troubled womb disorders, disturbs and silences its host's mind and voice but Jorden's description also suggests intensifies the capacity to invent or perceive things not as they are but in non-realistic shapes and forms. In 'Aurora', the 'rape of reason' by the daughters of Night that creates the monstrous chimeras describes just such a link between disturbed and disturbing products of the womb and of the mind. The very different treatment of the pregnant poet in "When I Lay Inn', may suggest, as Patricia Crawford has argued, that woman and men possessed alternative knowledges about sexual matters to learned discourse, and that women's knowledge 'about the distinctively female bodily functions' generated 'a degree of scepticism about medical theories. ${ }^{33}$ Such knowledge, Crawford posits, was typically orally exchanged between women at sites like the lying-in chamber. These knowledges are made apparent insofar as they act as a context within which formally educated male physicians narrated their claims of superior insight or midwives like Jane Sharp nuanced those claims. ${ }^{44}$ Women claimed experience as the basis for their knowledge, experience of having witnessed and undergone childbirth, of having possessed just such a body and been in just such a condition as the one under scrutiny. Elizabeth Clinton's treatise on breastfeeding insisted that 'I leave the larger and learneder discourse hereof vnto men of art, and learning; only I speake of so much as I reade, and know in my owne experience. ${ }^{35}$ Jane Sharp's work of midwifery, intended to fill a gap in anatomical knowledge for midwives noted nonetheless that 'farther knowledge may be gain'd by a long and diligent practice, and be communicated to others of our own sex. ${ }^{46}$ For Gowing that authority accrued especially to married women and stems from women's 'physical and visual experience of other women's bodies'. She quotes the French physician Laurent Joubert's list of fourteen local and folk terms for loss of virginity which for Gowing 'hints at a whole landscape of local knowledges of the body, more metaphoric and in many ways more precise than the standard French or Latin of physicians' terminology. ${ }^{47}$ Revealingly, Joubert's list was produced to rebut claims of midwives and matrons' superior knowledge to surgeons is establishing matters of virginity. The satirical pamphlet The Ten Pleasures of Marriage (1682) refers, for the benefit of its

\footnotetext{
${ }^{43}$ See Patricia Crawford, "Sexual Knowledge in England 1500-1700" in Sexual Knowledge, Sexual Science, ed. Porter and Teich, 82. Jean-Marie Lutes, in his discussion of Anne Bradstreet's representations of the female body, notes that despite Bradstreet's evident familiarity with medical discourses about women's bodies, nowhere does she 'suggest that her womb was inciting her to immorality or even, on a less abstract plane, causing her illness." Negotiating Theology and Gynaecology: Anne Bradstreet's Representation of the Female Body," Signs 22. 2 (1997): 319.

${ }^{44}$ Jane Sharp, The Midwives Book (London, 1671).

${ }^{45}$ The Countess of Lincolnes Nurserie (Oxford, 1622), Sig. C2r-v

${ }^{46}$ Sharp, Midwives Book, Sig. B2.

${ }^{47}$ Gowing, Common Bodies, 41.
} 
presumed male readers, to the 'doctresses' attending the newly delivered mother whose several authorities are print, oral communication with one another and with doctors, personal experiment and 'sage Matron Experience'. ${ }^{48}$

What does it mean to depict oneself as writing from the lying-in chamber? Since childbirth was largely managed by women, the lying-in chamber represented one of the few sites where women's authority and experientially acquired knowledge held sway over men's. It was a space to which women regularly returned either as labouring woman, attendant, or midwife. The lying-in chamber is also the site of the cultural ritual as well as the biological experience of childbirth. Draughts and daylight are excluded and the room itself, David Cressy proposes, 'became a womb, warm, dark and comfortable', though this depiction of the womb is itself an imagined one. ${ }^{49} \mathrm{It}$ is peopled by its own exclusively female attendants, some of whom were invited, some who may have been there through a perceived 'right' of presence. ${ }^{50}$ For the birth itself the pregnant woman made the arrangements with attendants in advance and entered the chamber presumably at the onset of labour pains. Amongst families of sufficient wealth, the newly delivered mother remained there for up to a month post-birth, gradually moving from being bed-bound to first moving about the room and then about the house, each stage of the process lasting roughly a week. Lianne McTavish notes that within the chamber the maternal body (and the unborn child) remain hidden from sight and the midwife's sense of touch takes precedence over her vision, an upending of a traditional hierarchy of the senses that privileges a sense culturally associated with the feminine and with women's experiential authority. ${ }^{51}$ Access to the lying-in chamber is tightly restricted but if Linda Pollock is correct about a perceived 'right' to attend a neighbour's birth, then the lying-in chamber is both a deeply private but also an emphatically public space. ${ }^{52}$ In Adrian Wilson's recent reading of the lying-in process, it is

\footnotetext{
${ }^{48}$ A. Marsh, The Ten Pleasures of Marriage (London: 1682), pp. 135-138.

${ }^{49}$ David Cressy, Birth, Marriage and Death: Ritual, Religion, and the Life-Cycle in Tudor and Stuart England (Oxford: Oxford UP, 1999), 54.

${ }^{50}$ Linda A. Pollock, "Childbearing and Female Bonding in Early Modern England," Social History 22.3 (1997): 286306.

${ }^{51}$ See Lynne McTavish, Childbirth and the Display of Authority in Early Modern France (Aldershot, Ashgate, 2005), p. 81; Fissell, Vernacular Bodies, 149; Gowing, Common Bodies, 45-46. Plato commends sight in Timaeus: "Vision, in my view, is the cause of the greatest benefit to us." Plato, Timaeus, trans. by R. G. Bury, LCL 234 (Cambridge, MA: Harvard UP, 1999), (47a). See Constance Classen, "The Witch's Senses: Sensory Ideologies and Transgressive Femininities from the Renaissance to Modernity" in Empire of the Senses: The Sensual Culture Reader, ed. by David Howes (Oxford: Berg, 2005), for the association of "touch" with "the feminine sensory sphere" (70).

${ }^{52}$ See Purkiss, 141. Ulinka Rublack documents how in Germany attempts to disrupt birth and post-birth practices could become the subject of public legislation or litigation in her "Pregnancy, Childbirth and the Female Body in Early Modern Germany", Past and Present 150 (1996), 84-110.
} 
also a site of women's collective practice where the delivered mother is temporarily freed from the expectations of the marriage contract (to provide sexual services to her husband and physical labour for their household) and when her property in her body is returned to herself. ${ }^{53}$ Louis Schwartz's discussion of early modern birth practices emphasises that existing knowledge of the lying-in chamber relies on written records and that the 'practices which concern us were enacted as part of an oral culture that maintained a certain level of secrecy even in its own time. ${ }^{54}$ What can be said, with an eye to the seventeenth-century maternal mortality rate of between ten and sixteen per thousand births, is that the space functions culturally and biologically as a threshold between life and death. ${ }^{55}$ It is a transformative space where the body's boundaries are breached and eventually what is interior —in this case the child — is revealed. It is one in which women's biology is conjoined with sin, though one in which, Schwartz has argued, women, particularly in Protestant traditions, were encouraged to read themselves as 'suffering, anointed vessels for God's creative power, as partners with God in the ongoing creation of life. ${ }^{56}$ To write from this space is to write from a gynocentric space, circumscribed by an experience, authority and knowledge that is uniquely female, whose rules are oral, practice-based and to varying extents protected by legislative as well as cultural authority. To use it partly to situate and partly to authorise the writing of a poem is an intriguing act.

The poem opens with a mental flight from pain, a flight which might be read as a Platonic ascent, this in the context of Pulter's poetry more broadly which, as Hutton has demonstrated is 'infused with a Platonic understanding of the soul's relationship to God. ${ }^{57}$ But here this ascent is triggered by the desire to depart the suffering female body.

Sad, sick, and Lame, as in my Bed I lay,

Least Pain and Passion should bear all the sway,

My thoughts beeing free I bid them take their flieght

Above the Gloomey shades of Death and Night. (1l. 1-4)

\footnotetext{
${ }^{53}$ Wilson, 191-196 and 211-213.

${ }^{54}$ Louis Schwartz, Milton and Maternal Mortality (Cambridge: Cambridge UP 2009), 28.

${ }^{55}$ Schwartz provides a useful account of the difficulty of compiling accurate figures and contextualises the figures quoted through comparison of the modern maternal death rate in 'the industrialised west' of six to eight maternal deaths per one hundred thousand births. See pp. 30-1.

${ }^{56}$ Schwartz, 18.

57 Hutton, 85.
} 
The narrative of the poem rapidly moves out of the space of the lying-in chamber and the speaker's 'thoughts' travel into a Copernican cosmos where another pregnant body is encountered, divided between two states of light and dark:

Her Globious Body spacious was and Bright

That Half alone that from Sols Beams had Light,

The other was imured in shades of Night. (11. 9-11)

As Hutton has noted, this spherical moon is explicitly opposed to the virginal Cynthia that was a tired trope of Elizabethan let alone Stuart love poetry and that flawed image corrected:

Nor did shee seem to mee as Poets fain

Guiding her Chariot with a silver Rein

Attir'd like som fair Nimph or virgin Queen

With naked Neck and Arms and Robes of Green

Love sick Endimion oft hath thus her seen.

But as my thoughts about her Orb was Hurl'd

I did perceive shee was another World

Thus beeing in my ffancie rais'd soe fare,

This World apear'd to me another star,

And as the Moon a shadow casts and light

So is our earth the Empres of their Night (11. 11-22)

Pulter begins with the poetic feminisation of this astral body as a young virgin queen clad in green. One likely source here is Michael Drayton's Spenserian-influenced Endimion and Phoebe (1595). In that poem, the moon goddess, Phoebe, seeks out Endimion in response to his three years of faithful 
longing, and he on seeing her 'imagin'd she some Nymph had been,/because she was apparrelled in greene' ${ }^{58}$ The influence is clearest in Drayton's description of the moon goddess:

Throughout her kingdome she might walk at large

Whereof as Empresse she had care and charge

And as the Sunne vnto the Day giues light, guide,

So is she onely Mistris of the Night[.] $]^{59}$

The image of the moon as a green-clad goddess proposed by Drayton's poem- a colour associated with love-sickness and green-sickness, the "disease of virgins" — is substituted with one that is pregnant with self-contained possibilities. ${ }^{60}$ The moon is 'another World' and Pulter's lines produce a reciprocal vision where the moon and the earth both cast light, and for inhabitants in each world, the other is a star. ${ }^{61}$ There is a shift here in poetic registers from an implicitly outmoded model featuring 'love sick' plaintive swains to one of adventurous observation. ${ }^{62}$ As Hutton points out, the whole depiction of this universe in this poem shows Pulter's knowledge of the Galilean world picture first presented in Siderius Nuncius (1610). ${ }^{63}$ The female cosmographer-poet's perception triumphs over the distorted imaginings of male poets; revelations produced by one form of gaze, Galileo's, are used to cancel the vision created by another. ${ }^{64}$ This strategy of privileging observation in her thinking and writing may also be demonstrate a particular idea of the poet's powers. Anne Sheppard observes that in the Neoplatonist model, poets are admired 'not for any ability to create

\footnotetext{
${ }^{58}$ Michael Drayton, Endimion and Phoebe (London: 1695), sig. C1r. The influence of Drayton's Poly-olbion on Pulter's chorographic poems is noted in Eardley, p 52 37n.

${ }^{59}$ Drayton, Endimion, Sig. D1v

${ }^{60}$ The overlap between lovesickness and greensickness is discussed in Helen Kay, The Disease of Virgins: Green Sickness, Chlorosis and the problem of puberty (London: Routledge, 2004), pp. 35-40.

${ }^{61}$ For the argument that the earth and the moon 'receives light in the same way from the other', see Johannes Kepler, Conversation with Galileo's Sidereal Messenger, trans. by Edward Rosen (New York: Johnson, 1965), p. 30.

${ }_{62}$ In Ben Jonson's 1620 masque News from the New World Discovered in the Moon the discoverer is a poet, newly returned from visiting the moon. See James Knowles, ed. News from the New World Discovered in the Moon in The Cambridge Edition of the Works of Ben Jonson, gen. ed. by David Bevington, Martin Butler and Ian Donaldson (Cambridge: Cambridge UP, 2012), 5.435.

${ }^{63}$ See Hutton, p. 81. I would add two other possibilities to Hutton's discussion of when and where Pulter encountered Galilean ideas, either that Pulter had access to (now lost) manuscript translations or to discussions of Galileo's works within an intellectual circle.

${ }^{64}$ Ann Rosalind Jones identifies the "mystery [of] and struggle" (144) with a silent and inconsistent beloved as generative of Maurice Scève's sixteenth-century Neoplatonic sequence Délie in particular and of male-authored Neoplatonic sequences in general. Scève figures his beloved as the moon. Ann Rosalind Jones, "Assimilation with a Difference: Renaissance Women Poets and Literary Influence," Yale French Studies 62 (1981), 135-153.
} 
new worlds but rather for an inspired capacity to reveal what was always there for those whose souls can rise to apprehend it', a description which very precisely describes the trajectory of this lyric. ${ }^{65}$ It is the idea that the mind is drawn out to recognise what it already knows that, Dominic Scott argues in the same volume, underpins Socrates' description of learning as a process of giving birth in Thaetetus, the same description cited by Maus as crucial to the development of the 'poet-in-childbirth' topos. $^{66}$

In this poem, Pulter's imagination stops at the limits of the material: she never represents herself as empowered to apprehend the divine but instead she travels precisely to the limits of existing but cutting-edge knowledge about the physical world, vividly illustrated in her next lines:

And now my Wonder is again renewed

That hee enlightening all could not bee vewed

Yet to my Reason this apeard the Best

That he the Center was of all the rest (11. 33-36)

The last three lines are the centre of the poem itself — lines 34-36 of 68 - and here an endorsement of Copernican theory confirms and extends a metaphor simultaneously Neoplatonic, Christian and Royalist, an elegant example of Pulter's analogical thinking where the cosmological, the political and the spiritual are encompassed and correlated through a single symbol. In The Republic Plato uses the sun as a metaphor for the superior form, the form of the Good and a commentary by Plotinus, the first Neoplatonist, made the sun a metaphor for what he called the One - the source of all things 'which is inaccessible to sense-perception but also to the intellectual operation of the mind'. ${ }^{67}$ Accessible only by inspiration, the One was easily Christianised as a symbol for God who sees but cannot be seen but nonetheless emanates the light by which the soul

\footnotetext{
${ }^{65}$ Anne Sheppard, "Plato and the Neoplatonists" in Platonism and the English Imagination, 17.

${ }^{66}$ Scott, "Reason, Recollection and the Cambridge Platonists", 149; Maus, 268-9.

67 Sarah Hutton, "Introduction to the Renaissance and seventeenth century", in The Platonic Imagination, 79. Sheppard, 7; Plato, The Republic, ed. and trans. by Chris Emlyn-Jones and William Reddy, LCL 276 (Cambridge, MA: Harvard UP, 2013), 6.507c-509a.
} 
sees itself as a shining sphere, a microcosm of the known universe. ${ }^{68}$ Copernican cosmology, unsurprisingly perhaps, enjoyed a royalist imprimatur as the royal sun is placed centre-stage. ${ }^{69}$

The invocation of the sun though is also a reminder that the speaker is in labour with a son and the centring of the writing body and the body of the poem on a homonym also points us towards another reading of the poem, as a map of the female reproductive body itself based on a model of the universe itself established through correction to popular assumptions about the bodies within it. In 'The Unfortunate Florinda' an alternative model to the humoral for women's bodies is proposed. Fidelia, a character distinguished for her rhetorical skill and story-telling abilities, engages in a debate with the misogynist Don Alphonso over the nature of women. She begins her defence of women with an assertion of their biological superiority: 'the works of creation rise by gradations until the woman who was the last and choicest of the works of nature was composed ... of the noblest elements,' - that is of the elements of air and fire. ${ }^{70}$ She argues specifically that women's bodies are of 'A more unctuous Ayrey or Ethereall nature than Man. ${ }^{, 71}$ Lightness unifies her adjectives: unctuous humours — those of oil or ointment — float on water; air is self-evident; ether, in Aristotelian natural philosophy, is the fifth element which fills the space beyond the moon and is the constituent substance of the stars and planets. ${ }^{72}$ The only element which moves in a circular motion rather than up or down, ether 'is of a higher nature' than the other elements, demonstrable by its distance from the sublunary world, and 'the primary body of all. ${ }^{, 73}$

This association of women's bodies with lightness and light insists on a Neoplatonist-inspired reading of women's bodies as literally closer to heaven. This idea occurs elsewhere in Pulter's work.

\footnotetext{
${ }^{68}$ The soul, having divested itself of any vestige of the body "by its own eternity having intellection of the eternal, he will see all things in this Intellectual substance, himself having become an Intellectual Cosmos, and all lightsome illuminated by the truth streaming from the Good..". Plotinus, The Enneads, ed. and trans. by Stephen MacKenna and rev. trans. by B. S. Page, $4^{\text {th }}$ ed. (London: Faber, 1969) IV.7.10. For the soul as a sphere, see Enneads V.8.9. 69 Jerome de Groot, Royalist Identities (Basingstoke: Palgrave Macmillan, 2004), 13.

${ }^{70}$ Eardley identifies the source of this argument as a discussion in Plutarch's Symposiacs as to whether women or men are hotter. See Poems, 332, fn. 298. In Holland's translation, which Pulter uses, women's bodies are described as containing "unctuositie or oileous matter, which quickly taketh fire, and will burne as light as a torch" (Philemon Holland, trans. The philosophie, commonlie called, the morals written by the learned philosopher Plutarch of Chaeronea (London: 1603), 688.

${ }^{71}$ Pulter, The Unfortunate Florinda, in Eardley, ed. Poems, 332.

72 "Thus they [the ancients], believing that the primary body was something different from earth and fire and air and water, gave the name aither to the uppermost region, choosing its title from the fact that it "runs always" and eternally. (Anaxagoras badly misapplies the word when he uses aither for fire)." Aristotle, On the Heavens, trans. by W. K. C. Guthrie, Loeb Classical Library (Cambridge, MA: Harvard UP, 1939) 270 b 20.

${ }^{73}$ Aristotle, On the Heavens, 269 b 15; 27065.
} 
In her poem, 'The Revolution', the speaker imagines her death and bodily dissolution in terms evoking the alchemical cycle of calcination and sublimation, the latter, as Archer points out, 'describes the transformation of matter into spirit, into the quintessence, from which all heavenly bodies are composed. ${ }^{, 74}$ The speaker imagines her body as being transmuted from element to element, passing through dust, water, air and finally fire:

And as I now burn High and clear

Let mee noe Prodigie apeare

To put the guilty World in feare

ffor love and Zeale my Breast inflames

Then follow all Heroick Dames

It will imortalize your fames (11. 39-44)

Her address is specifically to women and imagines a form of transmutation into a comet or the star of a constellation to which their names will be attached. This imaginative placement in light values the refined body as cosmic matter that legibly communicates the self's transformed and elevated moral status.

However, rather than ending at the point of highest ascent, 'When I Lay Inn' concludes with a descent that narrates the return to the body, following a path through a cosmos once again populated by maternal bodies:

Just as the Howers Auroras Curtain Drew

At which the Uglie Wife of Accharon

Bid drive and slashed her Drousey Monsters on

With Her there went her first born Brat old Errour

And ffierce Eumenedes poor Mortals terrour (11. 50-54)

74 "The Revolution", fols. 36r-37v (fol. 37r); Archer, 6. 
Night's first-born brat, Error, has echoes of Spenser's Error and there may be an anticipation of Milton's 'Sin' here but the point being made is that Error is a product of the absence of Light. The poem's description of Night and Error escaping the dawn inevitably recalls the position of the speaker:

To our Antipodes they took their fflieght

Sins cursed ofspring with their Dam did Trace

That most Prodigious incestuous Race

Pale gastly shudring Horrour lost despair

And sobbing sorrow tearing of her Hair

These of her sable Womb were born and Bred

And from the Light with her now frighted fled (11. 58-64)

The Biblical judgment 'in sorrow thou shalt bring forth children' (Genesis 3:16 KJV) is reimagined and externalised as a function of night and darkness and sin, just as the poem returns to the interior of the lying-in room, and the description of Night's labour becomes a description of the speaker's:

And then my Mayds my Window Curtains Drew

And as my Pain soe comforts did renew

Unto the God of truth, Light Life, and Loue

Ile such layes Here begtin shall end aboue. (11. 65-69)

The maids' actions are described in a line which mimics but reverses the drawing of Aurora's curtains prevent the dawn from illuminating the room and the body makes its presence known once again through pain: despite the reference in the title to 'lying-in', these seem again to be labour pains, either of physical or literary progeny. The return to the body exerts its own influence on what the speaker sees: pain prompting and shaping the vision of Night and Error, not Platonic revelation now but poetic creation. The dualist mentality present throughout the poem constructs a hierarchy of poetic art: the highest flights are those in which the speaker experiences cosmological and spiritual 
revelation, privileging both sight and light; it is on the descent in the representation of the monstrous and the pained body that ideas of the literary imagination are reinvoked. The four lines are difficult to interpret. It is not clear if a full stop should be understood after 'renew'. If the last two lines are treated separately, the final line seems to mean 'I will end in heaven the poems that I begin [to write or sing] to God here below.' This is the comfort that renews itself with her pain. On this reading, the voyage on or after the point of childbirth which begins the poem becomes an anticipation of the voyage the speaker will begin at the point of death. The image of the dying woman singing 'lays' to God fits neatly with contemporary descriptions of the 'good death'. 75 The copyist's emendation of the tense from 'begun' to 'begin' promises this final resolution and return in the cycle, casting a Christian veil over its recurrent combination of sin, pain and poetry thus repudiating the images produced in the poem's 'descent' narrative. ${ }^{76}$ The uncertain tense does draw attention to the question of whether or not this poem forms part of that godly poetic. The reading 'begin', (which makes slightly better sense of the line) implies it is not; 'begun', that it is.

By making the lying-in chamber the site of writing, by linking poetic creativity to the pain of a labouring body, a hierarchy of poetics is created by Pulter's literalisation of the link between biological and literary creation, a hierarchy that privileges revelation over creation. The trope of the labouring body is used to establish a continuum between Night, Error, Sin and the speaker through her own immurement in a space of darkness. This forms part of the wider practice in Pulter's work of associating the body with darkness, pain, emotion and memory, and as the site on which restrictions of her movements are inscribed. It is from here that links between poetic creativity and the intellectual flight from a secure interiorised space are also problematised. In its sealed off state the lying-in chamber has a certain affinity, as Maus points out, with the enclosed spaces that are regularly treated in early modern lyric as privileged sites of interiority. ${ }^{77}$ It also resembles (and disavows) Spenser's enclosed garden, a medieval topos that symbolised both the enclosed and the fertile female body and served as an 'emblem of the creative mind in the act of poesis, making. ${ }^{78}$ However, these poems typically use enclosed spaces to assert the subject's security against

\footnotetext{
${ }^{75}$ See for example Philip Stubbes' description of his wife Katherine's psalm-singing on her deathbed in his very popular A Christall Glasse for Christian Women (1592), sig. C3v. The ESTC records sixteen subsequent reprints. ${ }^{76}$ Given how minor the correction is (a single letter) I have not found it possible to determine whose hand amends the verb. The possibilities include the copyist's, Pulter's own or a subsequent reader's.

${ }_{77}$ Maus, pp. 273-74.

${ }^{78}$ Stevie Davies, The Idea of Woman in Renaissance Literature: The Feminine Reclaimed (Brighton: Harvester Wheatsheaf, 1986), 87.
} 
penetration - a secured body equals a secured self — whereas the production of this poem is initially explicitly tied to the permeability of the female body's boundaries and the poetic self is identified with the space outside that body. The closure of the curtains at the conclusion of the poem is a moment where an ecstatically liberated thought - a thought predicated on vision and therefore light — is reinterred in a small, enclosed space that does not constitute a little room of poetic freedom, identity or sanctuary. To write from the lying-chamber is not then the same as writing from the prison-cell or the study nor does the analogy of the 'chamber' with the 'womb' support ideas of writing from the body: the poem narrates a complex relationship of escape from and despairing reintegration with the enclosed writing body.

Nonetheless, a second reading suggests the necessity of that body to a full understanding of original and literary creation. Pulter's rewriting of the poet-in-childbirth trope is also a moment of selfrecognition. The speaker gives birth to herself as mother and poet, to offspring of the body and offspring of the mind. The poem with its own emphasis on unboundedness is brought into being by the experience undergone by the 'unbounded' pregnant body. ${ }^{79}$ Is Pulter, however, offering a redemption of the female body or simply a more literal response to an already complex poetic trope that identifies the creative imagination with the female body, writing herself into rather than out of a male tradition? Her poem is disruptive of traditional poetic accounts which figure women's bodies as unstable reflections of a desiring male gaze and through her poetics of revelation, she literally rises above a tradition of fallen and feminine creativity figured in allegory and asserts the metonymic qualities of soul and universe, poem and poet. Moreover she specifically ties that revelatory moment to the body giving birth and her account makes the maternal body a platform for ascent as well as the basis for the fall. This reworking appears tied to the direct experience of the pregnant body: Iris Young's description of that state as something which 'renders fluid the boundary between what is within myself, and what is outside, separate. I experience my insides as the space of another, yet my own body' offers a compelling modern gloss on Pulter's poem that sits alongside a more historicised recognition of the poem's debt to Galenic models of bodily porosity. ${ }^{80}$

\footnotetext{
${ }^{79}$ Elizabeth Grosz describes the experience of pregnancy as "ambiguous and unbounded" ... "we can no longer definitively specify whether it is one subject/body or two that is in question." Volatile Bodies: Towards a Corporeal Feminism (Bloomington and Indianapolis: Indiana UP, 1994), 108.

${ }^{80}$ Iris Marion Young, On Female Body Experience: "Throwing Like a Girl" and Other Essays (Oxford: Oxford UP, 2005), 49.
} 
Pulter's work explicitly challenges the largely male literary practice of tying the writing self to the secured and bounded (virginal) body. It disrupts the ambivalence of the pregnant poetic by creating her own anagogic relationship between writing and giving birth. Her poetic oscillates between using matter to think with — to understand, for example, the Galilean cosmos as a deeply material and sensuous thing analogous to the female body — and an intellectual and imaginative commitment to Christianised Neoplatonism which sees the body as something to transcend. ${ }^{81}$ The configurations of bodies - heavenly and human - offered by the early modern habit of thinking about worlds, minds and wombs by correspondence with one another offer Pulter a route in this poem to explore her own culture's positioning of her body and her writing and to construct a counter-perspective from which to survey it. The unusual element in the poem is that it manages simultaneously to endorse the dualist model as a mode which enables an imaginative transcendence of the feminine body and maintain a materialist emphasis that that transcendence is both enabled and limited by the body. The poem itself occupies the space — the threshold — between these two models of being, a state coterminous with the site of writing in the lying-in chamber. Despite its initial division between soul and body, therefore, it refuses a dislocation of voice from the body and any attempt to efface a specifically female speaking voice and vividly manifests the reciprocal agency of the material and the discursive in Pulter's own construction of her body and its works.

\footnotetext{
${ }^{81}$ Schoenfeldt sees a similar phenomenon in Book 2 of The Faerie Queene, where Spenser juxtaposes the "recurrent dualisms of neoplatonic spirituality" with the "aggressively materialist notion of self." (60) He notes that both are in service of exploring the movement from matter to spirit on which Spenser's poetics are based but are not easily reconciled with one another.
} 
Author biography: Ruth Connolly is a Senior Lecturer in Seventeenth-Century

Literature at Newcastle University. Recent work includes The Complete Works of Robert Herrick (co-edited with Tom Cain) for OUP and articles on 'The Sons of Ben' and on early modern editing. Forthcoming work includes an edition of the Complete Poems of Ben Jonson for Longmann's Annotated English Poets and a monography on the somatic in early modern poetry. 